\title{
Reading the Spatial Organization of Yalvaç Tıraşzade Mansion Through Cultural Codes
}

\author{
Pınar ÖKTEM ERKARTAL ${ }^{1 *}$ (D) \\ ORCID 1: 0000-0002-8564-8900 \\ ${ }^{1}$ Beykent University, Faculty of Engineering and Architecture, Department of Architecture, 34396, istanbul, Turkey. \\ *e-mail: pinaroktem@beykent.edu.tr

\begin{abstract}
Architecture and culture constantly interact with each other. Since the vernacular housing is built based on experience within the framework of the user's wishes and needs; it reflects both individual and social life strongly. Thanks to its unique spatial, structural and aesthetic features, "Turkish House" is a very important cultural heritage. In accordance with the lifestyle of the Turks, it has been shaped within the framework of principles such as adaptation to nature and the built environment, rationality, functionality, internal-external harmony (legibility), frugality, humanistic measures, regionalism, and flexibility. In this direction, the study aims to reveal the spatial organization of Yalvaç Tıraşzade Mansion within the framework of the "Turkish House". Turkish family life, social organization, climate characteristics of Central Anatolia, local riches, local acceptances are reflected in the spatial setup, facade, and details of Yalvaç Tıraşzade Mansion. In order to show this reflection, the building has been analysed over the cultural facts. In the study, where literature review and on-site observation were applied together as a method, a fiction flowing from the general view to the detailed examination of the case was chosen.
\end{abstract}

Keywords: Turkish House, Yalvaç Tıraşzade Mansion, Turkish culture, vernacular housing, space organization

\section{Yalvaç Tıraşzade Konağı'nın Mekânsal Organizasyonunun Kültürel Kodlar Üzerinden Okunması}

Öz

Mimarlık ve kültür birbiriyle sürekli etkileşim halindedir. Yöresel konut, herhangi bir uzman müdahalesi olmaksızın kullanıcısının istekleri, ihtiyaçları çerçevesinde deneyime dayalı olarak inşa edildiğinden hem bireysel hem de toplumsal yaşamı güçlü şekilde yansıtır. "Türk Evi" kendine özgü mekânsal, yapısal ve estetik özellikleri sayesinde geçmişten günümüze aktarılan çok önemli bir kültürel mirastır. Türklerin yaşam biçimine uygun olarak doğaya uyum, yapılı çevreye uyum, akılcılık, içten-dışa çözüm (işlevselcilik), iç-dış uyumu (okunaklılık), tutumluluk, insancıl ölçüler, yöresellik ve esneklik gibi ilkeler çerçevesinde şekillenmiştir. Bu doğrultuda çalışmanın amacı, "Türk Evi" çerçevesinde Yalvaç Tıraşzade Konağı'nın mekân kurgusunu ortaya koymaktır. Türk aile yaşamı, sosyal organizasyon, toplumsal örgütlenme, iç Anadolu'nun iklim özellikleri, yerel zenginlikler, yerel kabuller, Yalvaç Tıraşzade Konağı́nın mekân kurgusuna, cephesine ve detaylarına birebir yansımıştır. Bu yansımayı göstermek amacıyla yapı, kültürel olgular üzerinden analiz edilmiştir. Yöntem olarak literatür taraması ve yerinde gözlemin birlikte uygulandığı çalışmada, genel bakıştan detaylı örnek incelenmesine uzanan bir kurgu seçilmiştir.

Anahtar Kelimeler: Türk Evi, Yalvaç Tıraşzade Konağı, Türk kültürü, yöresel konut, mekân organizasyonu

Atıf/Citation: Öktem Erkartal, P. (2021). Reading the Spatial Organization of Yalvaç Tıraşzade Mansion Through Cultural Codes. Journal of Architectural Sciences and Applications, 6 (1), 11-24. DOI: 10.30785/mbud.801122 


\section{Introduction}

The Covid-19 pandemic once again reminds us of the importance of the concept and design of "home". While citizens in Turkey are advised to stay in their homes, many modern individuals who have not been able to leave their houses for weeks or even months have found it difficult to "fit their lives into the home". This is because the apartments, especially in the big cities, are not very suitable for the socio-cultural structure and traditions of the Turkish people, unlike the vernacular housing. Individuals often suppress, postpone, or have to meet these needs outside of the dwelling. These houses are either without a garden, even without a balcony, or with a rather insufficient balcony, and they are among concrete piles with their sparse closed spaces. These designs have not been able to adequately comply with the cultural codes of the Turkish nation, who love to be in touch with nature, like to have visual communication with the street and enjoy the pleasure of walking between open or semi-open and closed spaces during the day.

However, vernacular architecture, which has the social, structural, and aesthetic values to be transferred from the past to the future, acts as an extension of the culture. Since it is shaped and developed by the lifestyle of a society, it has the most suitable features for human actions and wishes, and then the geography, climate, and built pattern in which it is located. Vernacular architecture undertakes important tasks such as reflecting the history and dominant character of a region, giving hints about social life, and showing the technology and construction system of the period. It describes the local identity and provides diversity. The individuals reinforce their sense of belonging to their nation and country thanks to this architecture, which is born and shaped according to the characteristics of the society, of the land on which they were born and raised, and of the climate. With these features, vernacular architecture is like an "echo" of the daily and social life of people.

The article is mainly based on the assertion that social culture and lifestyle reflected and even shaped vernacular architecture and especially vernacular housing. In support of this argument, the complex relationship between culture and architecture was presented in the first part of the article concerning researchers, who have made detailed studies on the subject, including Edward Burnett Tylor (1871) and Amos Rapoport $(1969 ; 2004)$. Following this, the reflection of the culture in the Turkish House and its spatial features were examined based on data obtained from the studies of Sedad Hakkı Eldem (1954; 1984), Önder Küçükerman (1973; 2007), Doğan Kuban (1975; 1995), Şengül Öymen Gür (2000), Cengiz Bektaş (2016) and Ferhan Yürekli (2018). The spatial formation of the Turkish House has been compared with universal design parameters and cultural codes; the interaction between these has been examined and then tabulated. In this context, this analysis reveals the original aspect of the study and it is accepted as the contribution to the literature through the Turkish House and culturearchitecture interaction.

\section{Material and Method}

In this research, qualitative method was used. According to Denzin and Lincoln $(1998$, p.3) "the qualitative research is multi-method in focus, involving an interpretive, naturalistic approach to its subject matter". In this study a fiction flowing from the general view to the detailed examination of the case was created. Literature review and intrinsic case study were chosen as data collection tools.

The literature summary, which forms the first part of the study, involves the relationship between culture and architecture and especially the Turkish House typology. This typology is an important tool for the recognition and understanding of Turkish culture on a national and international scale. The theoretical background of the study has been established in the light of data obtained from national and international sources. In this context, the article begins with a brief summary of the spatial properties of the traditional Turkish House.

The case study, which constitutes the second phase of the research, Yalvaç Tıraşzade Mansion, one of the most significant examples of the Turkish House, is located in Yalvaç district of Isparta. The case study was carried out with on-site observations and examinations. The mansion has been chosen as the "living laboratory" of the study and was examined in 2016 during the workshop entitled "Psidia Antiokheia'dan Geçerken Mimari Denemeler, Değmeler, Değinmeler" (Architectural Trials, Contacts, 
Valuations While Passing through Psidia Antiokheia). After collecting the data from site observations, it was also supported by written information, technical documents and high resolution photos obtained from Yalvaç Municipality Archive in 2019. The building has been analysed by focusing on its spatial units one by one and read hermeneutical in the context of cultural codes. The findings were summarized with tables, containing technical drawings and photographs (the copyright of the photos and technical drawings in tables belongs to the Yalvaç Municipality) underlining the following spatial attribute: culture affects the spatial organisation of a living space.

\section{Culture, Daily Life and Architecture}

In the Oxford Advanced Learners' Dictionary culture is defined as "the customs and beliefs, art, way of life and social organization of a particular country or group". Similarly, Tylor (1871) defined culture as a "complex whole which includes knowledge, belief, art, law, morals, custom, and any other capabilities and habits acquired by man as a member of society". Therefore, culture includes all kinds of concrete and intangible assets that reflect the unique aspects of societies regarding lifestyle, belief, tradition, heritage, knowledge, and technology concerning both today and the past.

Culture is a very abstract concept and is often regarded as an explanation for humanitarian actions and similar randomness in these actions (Rapoport, 2004). However, culture also contains concrete values and therefore it would not be wrong to say that it acts as a general framework in all social applications where environment and human relations are at the forefront. Thus, it is an important factor in the production of any discipline that concerns the individual and the community to which it belongs. In this sense, culture is also directly related to the discipline of architecture, whose main purpose is to serve the physical, cognitive, and spiritual needs of humanity. According to Kuban (2010, p.20), the peculiar qualities of culture are an important factor that determines structural formation beyond quantitative needs. Similarly, Rapoport (2004) mentions that human behaviour changes according to culture, and the need for space varies accordingly. According to him, lifestyle leads us to actions and actions become the most important function in architectural design.

There is a symbiotic relationship between architecture and culture. While life and culture shape architecture, architecture enables them to be transferred to the future. At this point, the concepts of "traditional architecture" and "vernacular architecture", which we can consider as a subset of the former, gain importance. In this text, traditional architecture is recognized as "any construction that reflects the symbols of culture and offers the most appropriate solutions to environmental conditions and human needs, stemming from the direct relationship and experience that people have established with their environment throughout history". The vernacular architecture refers to the customisation of traditional architecture according to the characteristics of a particular place. Therefore, vernacular architecture was born out of years of tried and approved form and construction techniques as a return to the daily life of a local people. As emphasized by Yürekli $(2018$, p.11), beyond being a frozen end product, it is closely intertwined with life and reflects a dynamism. As a result, it can be boldly said, vernacular architecture is an expression of the culture and daily life of a certain group.

\subsection{Reflection of Culture to Vernacular Housing}

Housing, which is an important part of architecture, is a physical phenomenon intertwined with people. "It has emerged as a result of the material and spiritual conditions of life" (Kuban, 1995, p.12) and will continue to exist as long as humanity exists. It is possible to mention many factors that affect a house's design. These can be roughly grouped as the physical and the technological. Physical factors include all kinds of natural characteristics such as climate, topography, and seismic data related to the geography where the structure will be built. Technological factors include all kinds of factors related to building construction, from building material to construction techniques. However, these two groups of factors are not enough to transform a physiological environment into the concept of the house, a cultural, sociological, and spiritual environment. So the house is more than just a type of structure: it is the most important place that allows people to "dwell".

The concept of "dwelling" is used by Heidegger (1971) to describe the natural existence of mortals means the integration of the human being with his/her environment where he/she belongs and thus 
he/she becomes aware of his/her existence in the world. One of the functions of architecture, which witnesses and actually prepares the background for this existence, is to embrace and reflect the cultural, social, psychological, and religious values that enable people to identify themselves with their environment. Otherwise, space will not go beyond being built; that is to offer "dwelling" and support human existence. So cultural beliefs and preferences (Rapoport, 1969; Gür, 2000), societal values (Mazumdar and Mazumdar, 1994), symbols (Lawrence, 1985; Low, 1988), socio-cultural factors such as social relations or social organization and personal tastes are the main things that transform a building into a dwelling or a house. They enable an architectural structure to be a place for everything that will reinforce human belonging to life.

Shaped by cultural values, the housing is a pattern that meets the psychological and socio-cultural needs of people beyond being an indoor space that provides the physical conditions necessary to sustain the life of the individual only by responding to his/her simple biological needs (Gür, 2000, pp. 11-59). This private space, which is the refuge of the individual in everyday life, is a getaway point like a personal temple, where the human being feels comfortable, safe, warm, peaceful, and protected from the negativities of daily life. In addition to satisfying feelings such as individuality and privacy as well as unity and belonging, it helps people to express themselves and creates a background for primary memories that are the characteristics desired in a house (Kellekci and Berköz, 2006, p.169). Therefore, the individual has wanted to reflect all the values she/he believes to be a part of him/herself to his/her home, which is an extension of her/his existence. This reflection has allowed the culture to be read and understood almost perfectly through the settlements that have been accepted as the immovable heritage of civilizations throughout history.

In this context, vernacular housing could be a perfect indicator and record of life. It is built based on experience, according to people's wishes, needs, and own means, without any expert intervention. As it is shaped by the essence of the region and society, it is both the home and the mirror of the sociocultural and psychological values of its user. It is possible to read the structure of society, nomadic or settled, its history, family structure, social order, beliefs, traditions, preferences, and even its economy through vernacular housing design. Vernacular housing contains clues about the climate, vegetation, topography, and underground resources of the place where it is built, but it also shows both common features and simultaneous or sequential variations due to cultural interactions. Yet it is known that housing types with similar characteristics take different names according to the regions. However, no matter how diversified, it should be remembered that design parameters that form the basis of any type of vernacular housing arise from the requirements of culture and everyday lifestyle.

\subsection{Turkish House}

"Turkish House", the first concept that comes to mind in Turkish traditional architecture, has spread over a wide geography. It is a very important cultural heritage that is transferred from past to present thanks to its unique spatial, structural, and aesthetic features. Architect Sedad Hakkı Eldem (1954, p.11), who analysed the Turkish House and continued to keep it alive with his designs, defined it as "...house type settled in the borders occupied by the old Ottoman State, in Rumelia and Anatolia with its old names, developed and held up for 500 years, formed with its own characteristics." According to Doğan Kuban (1975), the Turkish House is "a type of housing that has met the needs of Turkish people for centuries, showing the shape and planning characteristics of the traditional Turkish family in accordance with their life-culture and ceremonies." Küçükerman (2007), on the other hand, describes the Turkish House as "an interesting living environment that Turks have realized in Anatolia for centuries".

In the academic literature, it is seen that this building type is named with other concepts such as "Ottoman House", "Ottoman-Turkish House", "Anatolian House" or "Anatolian-Turkish House" in line with the variations emerging according to the geography and climate it is applied to. However, despite all these different views, the structures that the mentioned typologies embody in practice have been determined to unite in a common cultural language (Tuztaşı and Aşkun, 2013, pp.273-278).

Sedad Hakkı Eldem has associated the derivation of the Turkish House in different regions with the variability of the region's climate, material, and culture, and argued that despite these differences, a 
common planning scheme has been formed. According to Eldem (1954), the social and economic situation of a house, like the culture it belongs to and other items it contains, can only be read from the plan. At this point, the plan becomes the most important element for the Turkish House and is shaped by three main elements: rooms, "sofa"s (Sofa is a technical term for the hall specific to the Turkish House. This term will be used in Turkish throughout the article.), and circulation (passages and stairs).

Aksoy (1963) and Küçükerman (2007) stated that the cultural values coming from the nomadic period and the settled culture of Anatolia have a great share in the shaping of the Turkish House. According to these researches, the values from the nomadic tent and the first housing examples of Anatolia are combined in the cultural language that makes up the Turkish house. This cultural language also contains several general principles that emerge by the reflection of Turkish and Islamic traditions on space. Bektaş (2016, p.33) listed these principles as an adaptation to nature, adaptation to the built environment, rationality, functionality, internal-external harmony (legibility), frugality, humanistic measures, regionalism, and flexibility.

When the history of architecture is examined, it is possible to say that all these principles are actually universal design dynamics accepted in all cultures and geographies. However, the point that should not be forgotten is how the international principles have passed through the cultural filter. For example, adaptation to nature is an international design principle, but it is a cultural interpretation that nature is placed in a house with an inner courtyard and creates a space for most important daily functions. An inner void to obtain a natural air circulation is another cultural application of sustainability. These are the spatial reflection of the Nomadic Culture but they are also related to the privacy of family life, another significant cultural code. Similarly, designing a new structure suitable for the existing built environment is actually a requirement of the conceptual architecture, but realizing this as not to interrupt the view of others or the airflow is an indicator of the love and respect of the neighbour, which is a cultural value.

It is possible to relate the universal design principles that shape the Turkish House with cultural codes. The way the cultural codes are used as the general design principle and the reflection of these principles on the space are summarized in Table 1.

Table 1. Cultural codes in the design principles that shape the Turkish House

\begin{tabular}{|c|c|c|}
\hline Cultural Code & Design Principle & Spatial Reflection \\
\hline $\begin{array}{l}\text { Nature Being a Part of Everyday Life } \\
\text { (Nomadic Culture) }\end{array}$ & $\begin{array}{l}\text { Ecology } \\
\text { Sustainability }\end{array}$ & $\begin{array}{l}\text { Inner courtyard } \\
\text { Open/semi open/closed space organisation } \\
\text { Compliance with topography } \\
\text { Climate-friendly design } \\
\text { Use of natural materials } \\
\text { Internal void providing natural air circulation }\end{array}$ \\
\hline Tolerance, Respect & Context & $\begin{array}{l}\text { Local architectural character } \\
\text { Not to obscure the view or cut the air of } \\
\text { other buildings }\end{array}$ \\
\hline Modesty & Purity & Plain design without ornament \\
\hline Ingenuity & $\begin{array}{l}\text { Rationality } \\
\text { Regionalism }\end{array}$ & $\begin{array}{l}\text { Using local materials } \\
\text { Sturdy and durable construction system } \\
\text { "Room" design containing all vital functions } \\
\text { Unified plumbing }\end{array}$ \\
\hline No Wastage & Functionality & $\begin{array}{l}\text { Optimum space dimensions } \\
\text { "Room" design containing all vital functions }\end{array}$ \\
\hline Being an Open Book & Legibility & $\begin{array}{l}\text { Reading the plan from the façade } \\
\text { Material honesty }\end{array}$ \\
\hline Humanism & Ergonomics & $\begin{array}{l}\text { Space and building elements suitable for } \\
\text { human scale } \\
\text { User-oriented space } \\
\text { Balance of private-common living spaces }\end{array}$ \\
\hline $\begin{array}{l}\text { Hospitality } \\
\text { Crowded Family Life }\end{array}$ & Flexibility and modularity & $\begin{array}{l}\text { Repetitive room typology } \\
\text { Additive-subtractive space } \\
\text { Private/semi-private common living spaces }\end{array}$ \\
\hline
\end{tabular}




\begin{tabular}{lll}
\hline Sociality & Fluidity & $\begin{array}{l}\text { Semi-open spaces establishing a visual and } \\
\text { physical relationship with each other }\end{array}$ \\
\hline Privacy of Family & Introversion & $\begin{array}{l}\text { Space organisation with "sofa" and inner } \\
\text { courtyard } \\
\text { A ground floor with blind walls }\end{array}$ \\
\hline Nomadic Culture & Modularity & $\begin{array}{l}\text { Multifunctional room design that meets all } \\
\text { the needs of a family }\end{array}$ \\
\hline Living with Animals & $\begin{array}{l}\text { Animal-friendly design } \\
\text { Sustainability }\end{array}$ & $\begin{array}{l}\text { The barn is located on the ground floor of } \\
\text { the house so that the family's livelihood is } \\
\text { safe and its heat is utilized. }\end{array}$ \\
\hline
\end{tabular}

\section{Space Organisation of Yalvaç Tıraşzade Mansion}

The Tıraşzade Mansion, which was repaired and renovated by Yalvaç Municipality and the ÇEKÜL Foundation and turned into a Municipality Culture House, is located in Yalvaç, a district of Isparta. Yalvaç is home to various civilizations and is known for the ancient city of Psidia Antiokheia. It was under the administration of the Ottoman State after Turkish Principalities such as the Ilhanlı Principality and Hamitoğulları. Kaş Neighborhood, which is within the scope of the protected area in the district, is the neighbourhood where the urban pattern and traditional house typology can be read best in the Ottoman Period (Güney, 2017, pp.7-20).

The old Yalvaç Houses are mostly two-story buildings, with a plain façade plastered with mudbrick, painted white and built with a wooden bearing system. Their hipped roofs are tiled. It is very common to see the blocks brought from the ancient city of Psidia Antiokheia up to the level of the basement in these houses with stone foundations. The ground floor, rooms, semi-open "sofa"s (also called "hanay" in this region), and service areas are spaces shaping the Yalvaç house.

The opaque ground floor, which is usually entered from the street with a double-wing wooden door, allows the daily work of the house to be carried out. This part of the house is also called "hayat" (life) and mostly surrounds an inner courtyard. The rooms are located on the upper floors and they have many functions, just like independent residences. Each room has a stove, beds raised to the storage areas on the walls during the day, and bathrooms hidden in a closet. In this way, it is possible to cook, eat, clean, and sleep in the same place. In the "hanay" (hall) in front of the rooms, there is the "köşk" (pavilion) section with the bay windows, where the family gathers, and the "serpin" (hold) section, where dry legumes are placed (Yalvaç Municipality Archive, rcv. 2019). Hanay is a semi-private, semipublic space surmounted by eaves, surrounding the inner courtyard. It allows family members living in different rooms to live together without being disturbed. Kuban (1995, pp.137-152) states that this space, which extends along the length of the rooms, performs multi-purpose functions from sitting to preparing food.

Tıraşzade Mansion, located in Kaşyukarı District, Kahveci Bekir Street, is a vernacular house with an introverted plan type like other houses in its vicinity. It was built with adobe and wood and has a wooden structure system. The first part was built in 1840 and it took its final form in 1911 (Yalvaç Municipality Archive, received in 2019). Due to the slope, the structure has two floors in the north wing and three floors in the south wing. Its exterior is plastered with mudbrick mortar and painted white, complying with the general feature of the old Yalvaç Houses. 


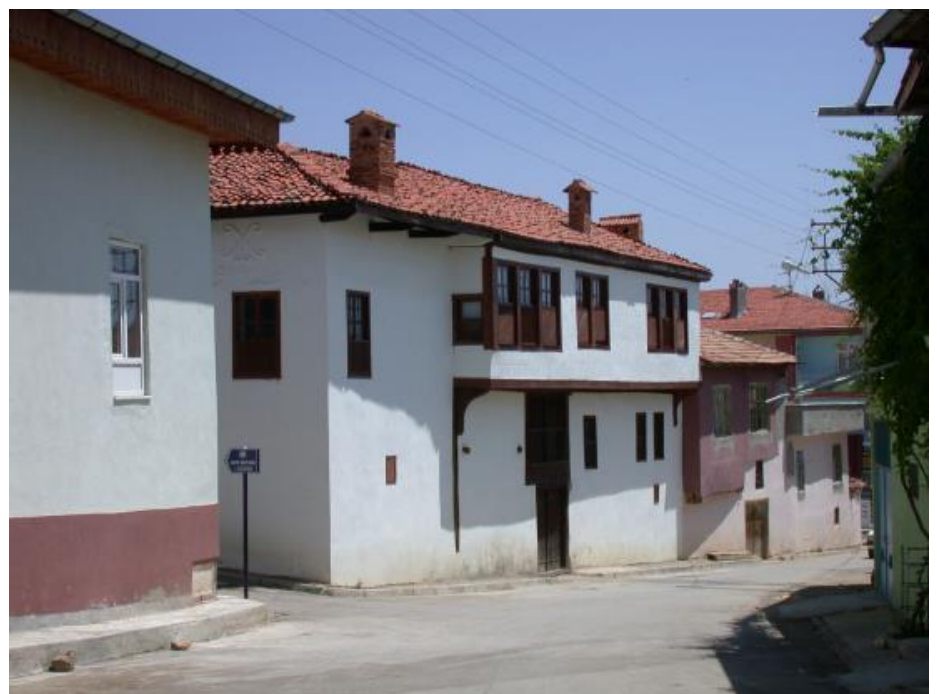

Figure 1. Tıraşzade Mansion, façade (Yalvaç Municipality Archive, rcv. 2019)

The entrance to the house is provided by a double-wing wooden door in the middle of the western façade. "Hayat" can be entered via a stone floor. It houses a barn, a "seki" (platform), a haystack, a warehouse, and multi-purpose rooms with low floors, and opens onto a small inner courtyard. This garden can be viewed from all floors. Wooden stairs one lead to the upper levels. At the upper level, the "hanay" is reached. It is a semi-open space surmounted by wooden eaves. This "sofa" continues across three faces on the upper floors in front of the rooms and contains elements such as the köşk (pavilion), divan, cabinets, hearth, and ablution area.

Each of the rooms listed behind the "hanay" has been designed to meet all the needs of a family. In the rooms, there are divans, platforms, fitted closets, a stove, and a bathing cubicle. The stove and bath are located adjacently. There are wooden cages that provide privacy at the bottom of the guillotine windows facing the street. The master room, which is located next to the mansion in the house, is accessed through a transition area (threshold), which prevents it from being seen from the common area and a kitchen on the east side of the house. From the southwest, one can reach the third floor of the south wing by wooden stairs. On this floor, the morphology of the second-floor plan continues and there are rooms, toilet, stove, and cupboards.

\subsection{Reflections of Turkish Culture in the Tıraşzade Mansion}

As can be seen from Table 2, the nomadic culture coming from the past, the historical values of Anatolia, the Turkish family structure, social organization, the climatic characteristics of Central Anatolia, local riches, and acceptance are reflected precisely in the design, space organisation, structure, façade and details of Yalvaç Tıraşzade Mansion.

Firstly, the mansion is L-shaped surrounding an inner garden. The ground floor walls are blind. The building is introverted and mainly interacts with the inner courtyard. This conservative form is a reflection of Turkish and Islamic culture, in which the privacy of family life is very important. The façade of the building is quite plain, unpretentious, and in harmony with the surrounding houses. This is a spatial echo of humility and tolerance. As a typical Turkish House feature, it is possible to easily read the plan from the façade. Again, the natural materials (wood, adobe, stone) used in the building are indicators of the importance given to healthy living and the environment. 

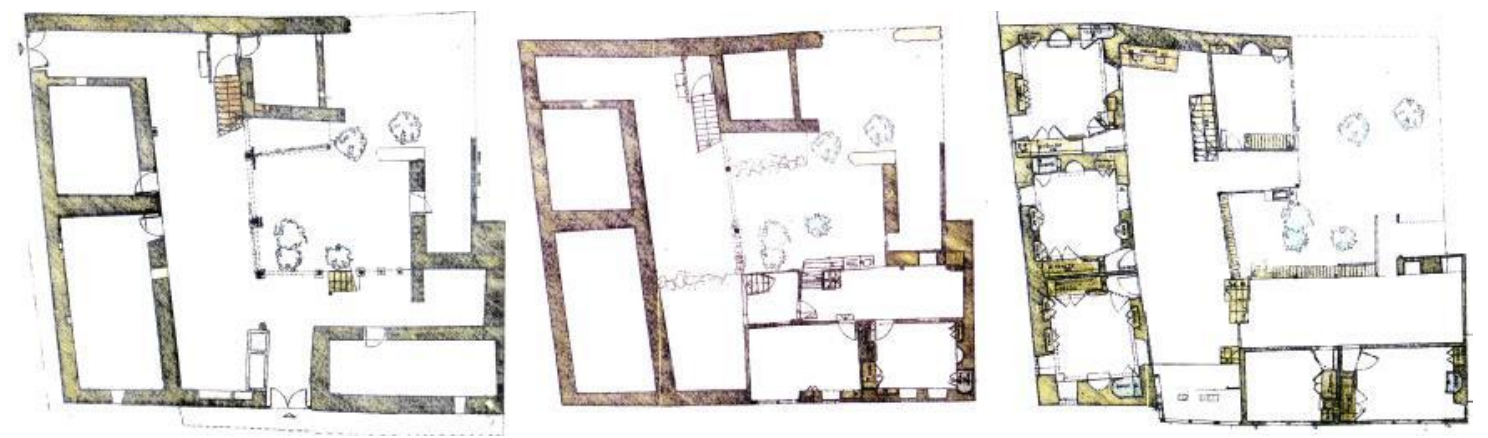

Figure 2. Tıraşzade Mansion, ground, first and second-floor plans (Yalvaç Municipality Archive, rcv. 2019)

Another important factor that makes Tıraşzade Mansion culturally important is the courtyard with the garden. The ground floor (hayat) with its open, semi-open, and closed spaces, ensures that the family is intertwined with nature, makes use of the soil when it is available, and daily tasks are carried out with ease, regardless of the climatic conditions. This place also ensures that life and natural air flow continuously in the three-dimensional interior void of the house, as stated by Yürekli $(2018, p .12)$. This translucent and permeable "daily life box" is the center of the circulation that the house has set up with both the street and other floors. Strong visual and physical relationships can be established in plan and section planes thanks to the vertical open space starting from the courtyard. Natural ventilation, plants, and areas related to organic nutrition (drying of the food and cultivation when necessary) enable a healthier life.

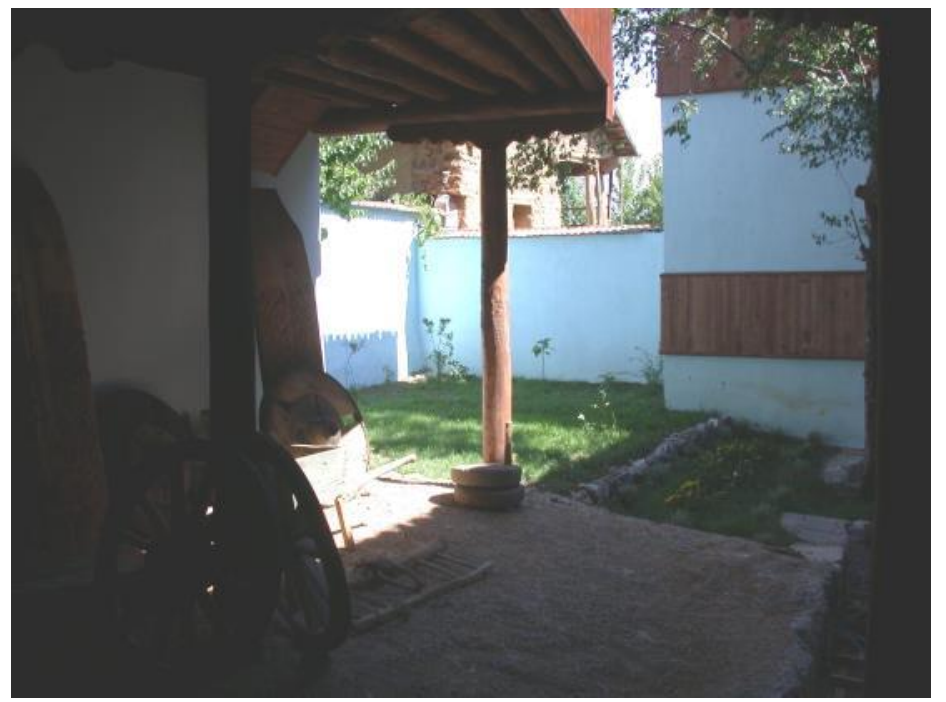

Figure 3. Tıraşzade Mansion, hayat, and garden (Yalvaç Municipality Archive, rcv. 2019)

Another important place of Tıraşzade Mansion is "hanay". It surrounds the inner garden vertically and receives both natural light and air. It is a functional place, protected from the hot sun in the summer and the rain in the winter. This is a semi-common area where rooms, each functioning as a private apartment, are connected. Since this place has different elevations, it provides visual communication with other family members, while creating for them personal space. Besides, it allows daily encounters and gatherings when desired and is the heart of domestic socialization. It enables children to spend quality time under the supervision of all family members and set up creative games. It makes it possible to view and enjoy the inner courtyard from different levels and directions. Furthermore, circulation continuity established through wooden steps between "hanay"s at different levels is an indicator of spatial fluidity. It also facilitates the transition adaptation from indoor to outdoor. 


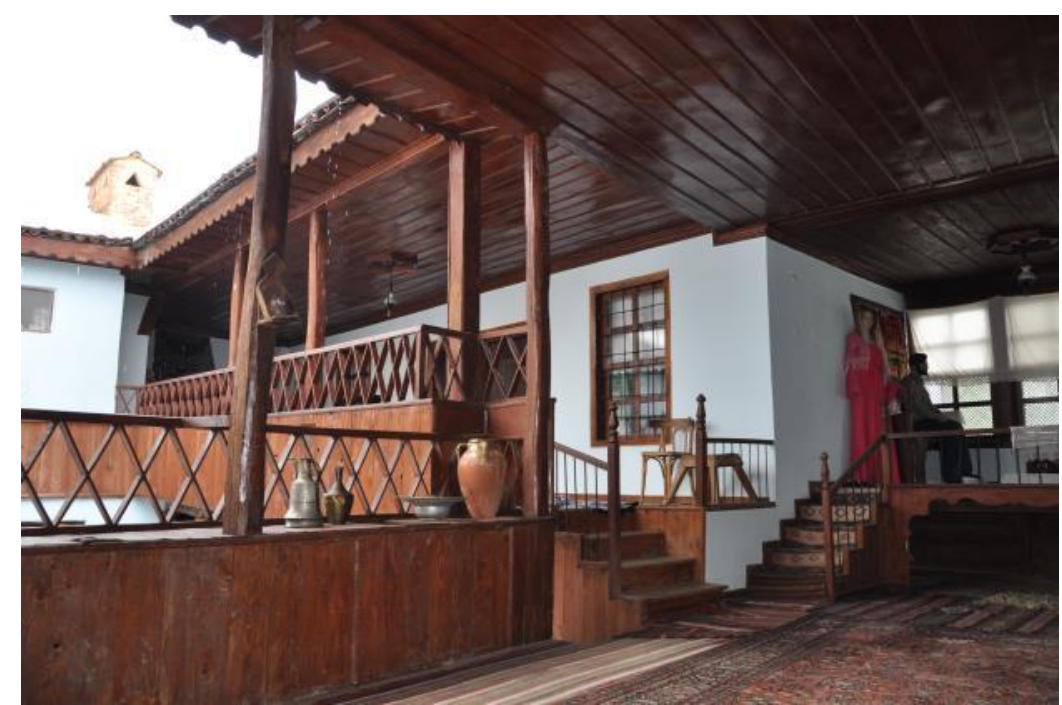

Figure 4. Tıraşzade Mansion, hanay (Yalvaç Municipality Archive, rcv. 2019)

"Köşk" (the pavilion) which is located just in front of the master room, is a specialized seating area that can be reached by a few steps from the "hanay". This field, which communicates visually with the street, is also the symbol of the hierarchy within the family structure. It is very functional since its lower part is used as a storage area.

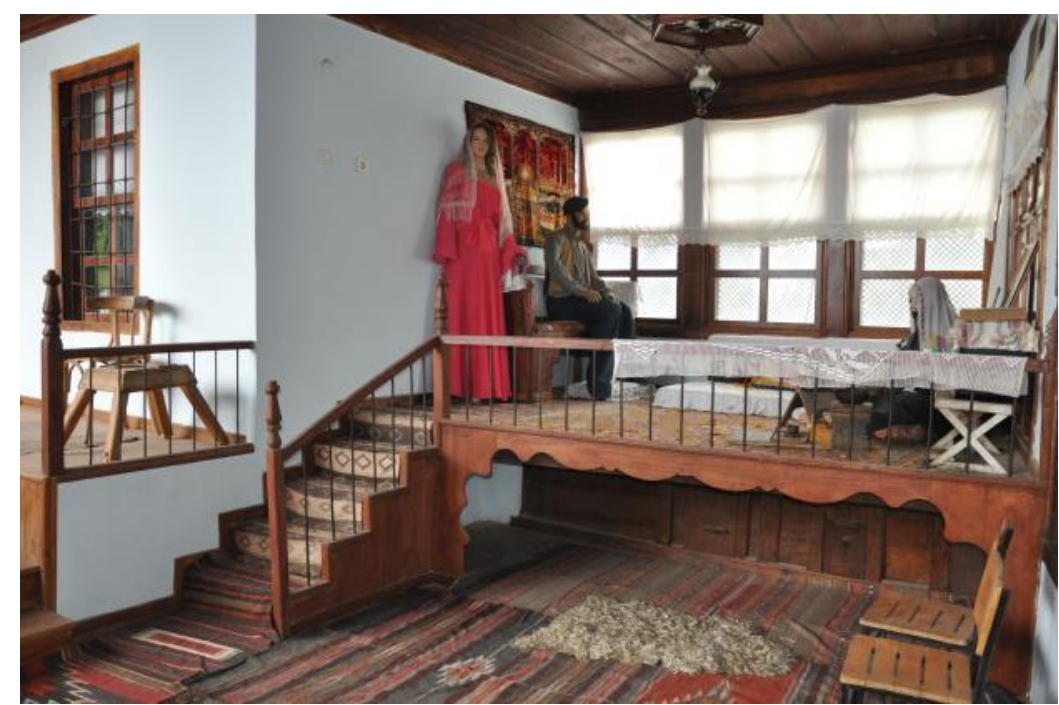

Figure 5. Tıraşzade Mansion, "köşk" (pavilion) (Yalvaç Municipality Archive, rcv. 2019)

The rooms, each functioning like a small, fully-fledged apartment, are the most suitable solution for the crowded Turkish family structure. In this way, the individual of each household living together has its own private space. The rooms where wood is the main construction material are modest, functional, and rational, suitable for human dimensions both in terms of furnishing and scale. There is no unnecessary or wasted space. It is suitable for being transformed or reproduced despite the possibility of family growth or shrinkage. It is modular and flexible. Therefore, it has the potential to adapt to family needs. 


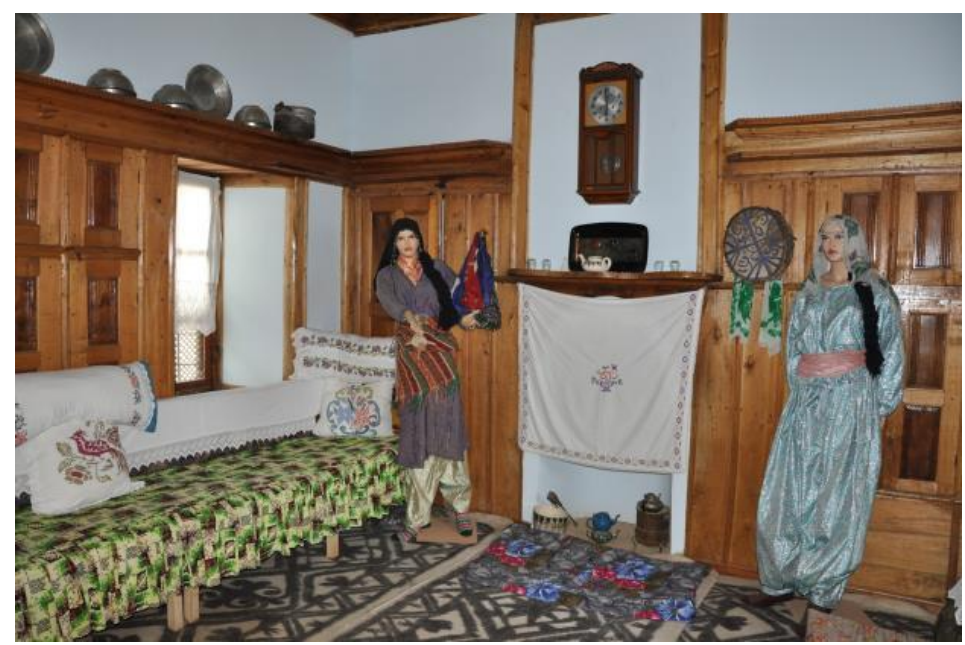

Figure 6. Tıraşzade Mansion, room (Yalvaç Municipality Archive, rcv. 2019)

In the design of the rooms, it is possible to see traces of the nomadic life of Turks from Central Asia. Turgut (1990) finds this trail in the location of the rooms and draws attention to the independence of the rooms, starting from the first floor. Göğebakan (2015) sees the nomadic culture in the systematic and rational solution of the room. Indeed, the room accommodates the family in a single place, just like a nomadic tent, to meet all their needs.

To summarize, Tıraşzade Mansion offers open, semi-open, and closed spaces for all family members to spend time with nature while allowing a crowded family to live together without disturbing each other. It allows the family to do their daily work without being affected by the climatic conditions and provides the privacy that the family needs (Table 2 ).

Table 2. Spatial and cultural codes in the Tıraşzade Mansion

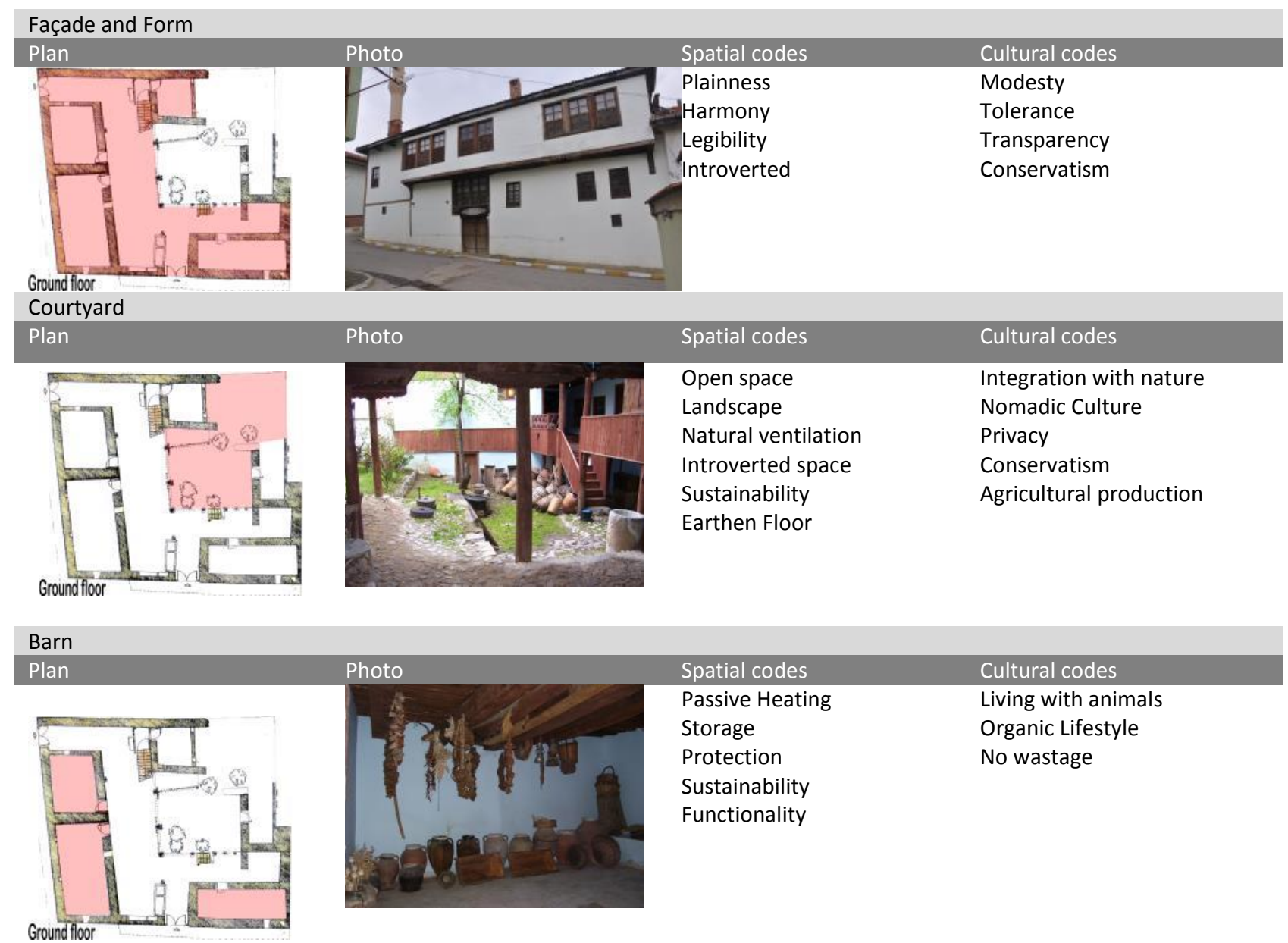


Journal of Architectural Sciences and Applications, 2021, 6 (1), 11-24.

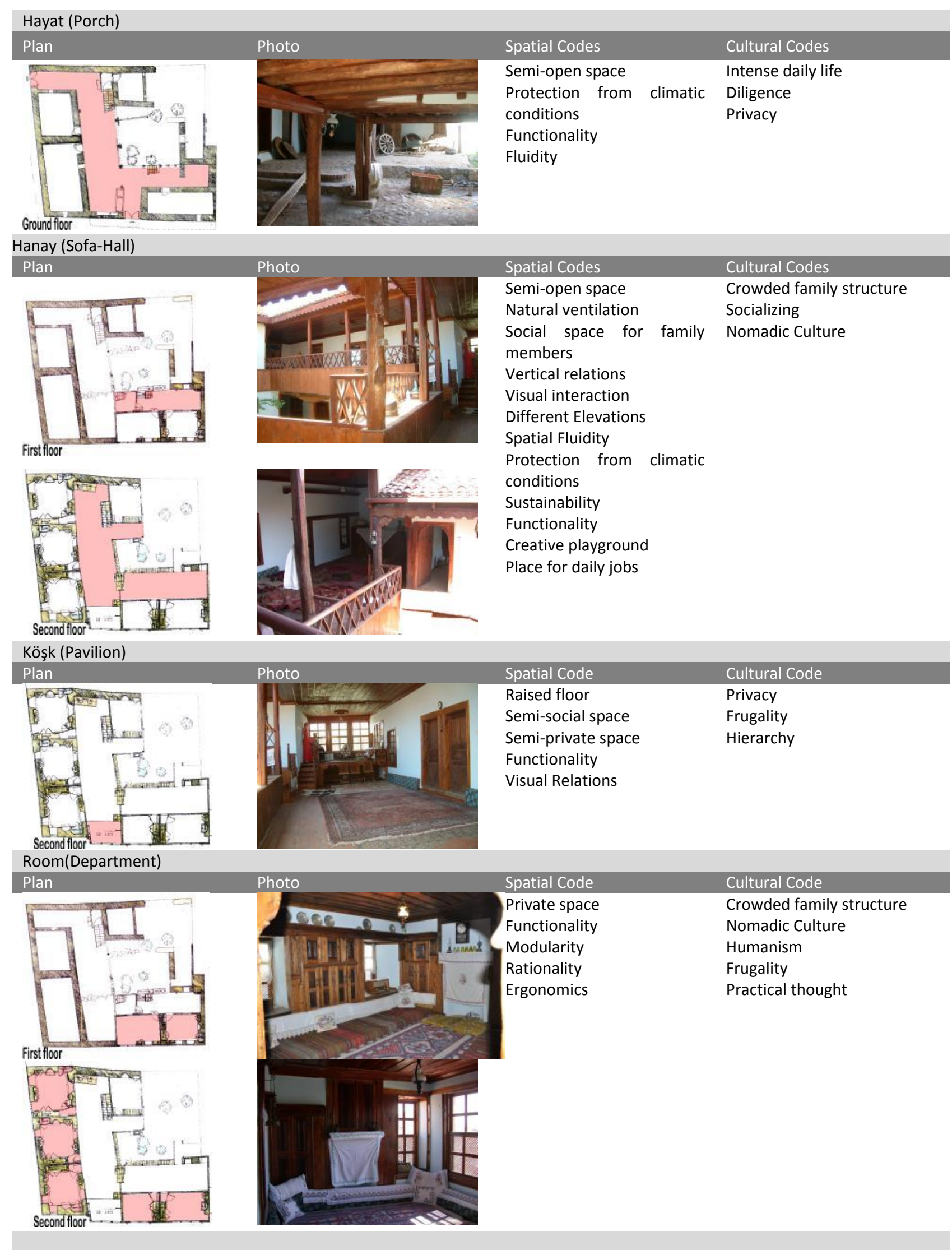

\section{Conclusion}

According to Heidegger $(1962 ; 1971)$, man's relationship with space is existential. Dasein (humanbeing) arranges the earth according to his own orientation while dwelling on it, that is, spatializes it. This rooting or settling is related to giving meaning to the existing environment. Space also gains its own priori character through the spatializing feature of Dasein. In that case, space is by no means 
considered in isolation from the things that occupy it and their earthiness. In short, space becomes meaningful with the presence of Dasein.

While each region creates its own culture according to the way of living, it also creates the architectural environment and spatial organization through this culture. Thus, culture and space change and vary depending on each other. Vernacular dwellings are built in line with the needs of people living in a place and according to the physical and social characteristics of the geography. Thanks to this construction, the building is almost transformed into a representation of the lifestyle. Since the vernacular housing is a structure born in the culture and shaped by it, it is the dwelling that has the most suitable features for human cultural codes. Studying the vernacular housing design and analysing spatial codes of the building, gives us information about the culture of the society.

Although it shows small differences according to the region as it is spread over a wide geography, the main principles that shape the Turkish House contain cultural codes related to the lifestyle of the Turks. These codes have enabled the universal design principles that make up the house to evolve through a social filter. In this way, a universal design principle has been reinterpreted with cultural code and turned into a national design input that forms the Turkish House. Values from all the phases that Turks have gone through their deep-rooted history have combined in the design language that constitutes the Turkish House. Thus, this typology reflects the elements of both the nomadic tent and the first residential examples of Anatolia in its spatial organization, kneaded with Turkish and Islamic tradition.

The close relationship of the Turkish people with nature and the importance of privacy in private life have created the house with an introverted plan scheme, a courtyard on the ground floor, semi-open spaces, and areas reserved for animals on the ground floor. The use of local materials, the optimum size of the rooms, and the way they are designed to meet all family needs are reflections of rationality and functionalism. The setup of the rooms and the "hanay" is the spatial interpretation of the balance between private and social life in patriarchal and crowded family life. Positioning each house in a way that does not interrupt the view and air of the other is the result of respect for the built environment. The lean exterior is a sign of modesty and thrift. In short, all cultural codes related to the daily life and history of the society are settled in the Turkish house and transferred from generation to generation.

In this context, Yalvaç Tıraşzade Mansion is a very important document in which both the features of the region and the daily life practices can be read. This building, designed as a case of Turkish house typology, is the embodiment of the codes of Turkish culture. Almost all of the cultural codes such as diligence, frugality, tolerance, modesty and the vital codes such as crowded family life, patriarchal family structure, intimate private life, and establishing visual relations with the street have become a spatial element in Yalvaç Tıraşzade Mansion and form the design.

Contrasting phenomena such as individuality-coexistence, indoor-outdoor space, living with natureprotection from nature have been successfully balanced within the spatial setup of the building. Different elevations, open-half open and closed spaces enrich the spatial experience of the individual, while parameters such as natural ventilation, natural materials, and natural heat sources reinforce a sustainable and healthy life. In addition to all these, the modest form and facade, the utilization of local resources, functional rooms, and optimum space dimensions approve the mansion as a rational and economical design. In this way, the dwelling that best responds to the climatic conditions of that geography and the existential expectations of the family has emerged. In this way, the dwelling that best responds to the climatic conditions of that geography and the existential expectations of the family has emerged. User expectations, needs, cultural requirements, and traditions are in harmony with the spaces that make up the building and with the building itself as a whole. Consequently, cultural values feed the space, and space nurtures the culture.

In contemporary times, the framework of vernacular architecture has been transformed, forgotten, or deliberately ignored by society. The relations between the street-house, child-parent, and individualnature are recoded in the buildings in the new cities. This is undoubtedly due to the increase in population density and changes in the lifestyle of the modern individual. It is pointless to ignore the formation dynamics of the apartments that have replaced the vernacular dwelling. However, no 
matter how much the individual changes, he still carries the cultural codes from the past, and this causes serious conflicts between the modern individual's conscious needs and what he can have.

This conflict has emerged visibly in the pandemic period we are in. On the one hand, individuals who want to be in touch with nature but cannot, who want to see their relatives but cannot see them, are trapped between four walls. On the other hand, all the troubles of the individuals who live together with their extended family but who are overwhelmed by the fact that they never have their own private space have become apparent. This situation is a result of the fact that cultural codes are no longer taken into account in housing designs.

As a result, the aim of this publication, which focuses on the spatial and cultural codes of the Tiraşzade Mansion within the framework of the Turkish House, is to underline the spatial potentials that can be obtained from here by drawing attention to the interactive relationship of the vernacular house with its culture. Although the spatial relations established in this building are not expected to be applied exactly in modern houses, it is hoped that this relationship will be taken into account in future designs when possible, with the examination of this mansion, which is one of the successful examples of cultural existence as an important input of design.

\section{Acknowledgment and Information}

I would like to extend my thanks to Yalvaç Municipality, which generously shared information and photos about the Trraşzade Mansion. The copyright of the photos and drawings in Table 2 belongs to the municipality. The article complies with national and international research and publication ethics. Ethics committee permission was not required for the study.

\section{References}

Aksoy, E. (1963). Ortamekân: Türk Sivil Mimarisinde Temel Kuruluş Prensibi [Central space: Basic Establishment Principle in Turkish Civil Architecture], Mimarlık ve Sanat, 7-8, 39-92.

Bektaş, C. (2016). Türk Evi [Turkish House], İstanbul: YEM Yayınları.

Denzin, N. and Lincoln, Y. (1998). Strategies for Qualitative Inquiry, Thousand Oaks, CA: Sage.

Eldem, S. H. (1984). Türk Evi I [Turkish House I], Istanbul: Taç Vakfı Yayınları.

Eldem, S. H. (1954). Türk Evi Plan Tipleri [Turkish House Plan Types], İstanbul: Pulhan Matbaası.

Göğebakan, Y. (2015). Karakteristik Bir Değer Olan Geleneksel Türk Evi'nin Oluşumunu Belirleyen Unsurlar ve Bu Evlerin Genel Özellikleri [Factors that Determine the Formation of Traditional Turkish House Having Characteristics Value and General Features Of These Houses], Inönü University Journal of Culture and Art, 1/1, 41-55.

Güney, E. D. (2017). Yere Dair [About the Place], in Bir Mimari Çalıştay Deneyimi: Psidia Antiokheia'dan Geçerken Mimari Denemeler, Değmeler, Değinmeler, E. D. Güney (ed.), İstanbul: Beykent Üniversitesi Yayınları, 7-20.

Gür, Ş. Ö. (2000). Doğu Karadeniz Örneğinde Konut Kültürü [Housing Culture in the Example of the Eastern Black Sea Region], İstanbul: YEM Yayınları.

Heidegger, M. (1962). Being and Time, J. Macquarrie and R. Robinson (trans.), New York: Harper \& Row.

Heidegger, M. (1971). Building, Dwelling, Thinking, Poetry, Language, Thought, A. Hofstadter (trans.), New York: Harper Colophon Books.

Kellekci, Ö. L. and Berköz, L. (2006). Konut ve Çevresel Kalite Memnuniyetini Yükselten Faktörler [The Factors that Increase Dwelling and Environmental Quality Satisfaction], Itüdergisi/a: Mimarlık, Planlama, Tasarım, 5/2, 167-178.

Kuban, D. (2010). Mimarlık Kavramları [Notions of Architecture], İstanbul: YEM Yayın.

Kuban, D. (1995). Türk Hayat'lı Evi [Turkish House with Hayat], İstanbul: Eren Yayıncılık. 
Kuban, D. (1975). Sanat Tarihimizin Sorunları [Problems of Our Art History], İstanbul: Çağdaş Yayınları.

Küçükerman, Ö. (2007). Kendi Mekanının Arayışı İçinde Türk Evi [Turkish House in Search of Its Own Space], İstanbul: Türkiye Turing ve Otomobil Kurumu.

Küçükerman, Ö. (1973). Anadolu'daki Geleneksel Türk Evinde Mekân Organizasyonu Açısından Odalar [Rooms in terms of Spatial Organization in Traditional Turkish House in Anatolia], İstanbul: Türkiye Turing ve Otomobil Kurumu.

Lawrence, R. J. (1985). A More Humane History of Houses: Research Method and Application, in Home Environments, I. Altman and C. M. Werner (ed.), New York: Plenum.

Low, S. M. (1988). Cultural Aspects of Design: An Introduction to the Field, Arch. \& Comport/Architecture and Behaviour, 4/3, 187-190.

Mazumdar, S. and Mazumdar, S. (1994). Societal Values and Architecture: A Socio-Physical Model of Interrelationships, Journal of Architecture and Planning Research, 11/1, 66-90.

Rapoport, A. (1969). House Form and Culture, Prentice-Hall.

Rapoport, A. (2004). Kültür Mimarlık Tasarım [Culture, Architecture, and Design], B. Selçuk (trans.), İstanbul: YEM Yayınevi.

Turgut, H. (1990). Kültür- Davranış- Mekan Etkileşiminin Saptanmasında Kullanılabilecek Bir Yöntem [A Method for the Determination of Culture-Behaviour-Space Interaction System], (Ph.D Thesis), İstanbul: ITU.

Turnbull, J. (ed.) (2014). Oxford Advanced Learner's Dictionary, Oxford University Press.

Tuztaşı, U. and Aşkun, i. Y. (2013). 'Türk Evi' İdealleştirmesinde 'Osmanlı Evi' ve 'Anadolu Evi' Kavramlarının Ortaklıklarına İlişkin İşlevsel Açıklamalar [Functional Explanations Regarding the Common Qualities of the "Ottoman House" and the "Anatolian House" within the Context of the Idealization of the "Turkish House"], Bilig, 66, 273-296.

Tylor, E. B. (1871). Primitive Culture: Researches Into the Development of Mythology, Philosophy, Religion, Art and Custom, London: John Murray.

Yalvaç Municipality Archive. (rcv. 2019). Municipal Culture House (Tıraşzade Mansion) Inventory.

Yürekli, F. (2018). Geleneksel Türk Evinde Düşey Yaşam [Vertical Features of "Turkish House”], Mimarist, $62,11-13$ 